\title{
ЯПОНЫ ЖИЖИГ ДУНД ҮЙЛДВЭРИЙН ХӨГЖИЛ, ЦААШДЫН ХАНДЛАГА
}

\section{Товч утга}

Б.Сэржав *

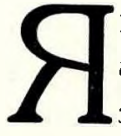

пон улсад дайны дараах эдийн засгийн сэргэлт, 60-70аад оны жигд өндөр хөгжил болон туүнээс хойших эдийн засгийн удаан хугашааны тогтвортой өсөлтийн явцад жижиг дунд үйлдвэр упс орны эдийн засгийн бүхий п сапбарт ихээхэн чухап чүрэг гүйцэтгэх болжээ. Өнгөрсөн зууны 80-аад он гэхэд жижиг дунд үйлдвэр нь том үйпдвэруудтэй бие биеэ нөхөн орших хэмжээнд хүрч, хөдөпмөрийн хуваарийн энэ тогтопцоо нь Японы шитаукэ систем хэмээн олон упсын хэмжээнд анхаарал татаж, улс орны эдийн засгийн өрсөлдөх чадварыг өсгөсөн гол хүчин зүйл гэгдэж байв. Жижиг дунд үйлдвэрийг хамарсан шитаукэ тогтолцооны хөгжлийн үр дүнд Японд түүхий эд материал боловсруулахаас эхлээд тоног тохөөрөмж, эд анги, бүтээгдэхүун үйлавэрлэх, угсрах бүх пронесс, өөрөөр хэлбэл дотооддоо бэлэн бүтээгдэхуүН хийх үйлдвэрлэлийн стил бий болсон юм.

2010 оны байдnаaр Японд нийт үйлдвэрийн газрын 99\%-ийг жижиг дунд үйлдвэр эзэлж, нийт ажиплагсдын 78\% нь тэнд ажилпаж, аж үйлдвэрийн сапбарт гэхэд п нэмүу өртөг шингэсэн бутээгдэхуүний талаас илүү хувийг жижиг дунд үйлдвэрт үйлдвэрпэж байна. Японы эдийн засагт сүүпийн үед бутцийн өорчлөлт явагдаж, үйлдвэруүд нь далайн чанадад олноор гарах үйл явц үргэлжлэн, аж үйлдвэрийн өмнөх стил өөрчлөгдөж байгаа хэдий ч эдийн засаг, нийгмийн ирээдуйн хөгжипд жижиг дунд үйлдвэрийн гүйцэтгэх үүргийг улам бүр чуххалчпан үзэх болж буй талаар тус өгүүпэпд авч үзлээ.

Түпхүур үг: Японы жижиг дунд үйлдвэр, давхар бүтэц, шитаукэ тогтолџоо, жижиг дунд үйлдвэрийн суурь хууль, хөөсөн эдийн засаг, бүтцийн өөрчпөлт

*Б.Сэржав - Олон упс судпапын хурээпэнгийн Япон судлалын секторын эрхлэгч, эрдэм шинжилгээний ахлах ажилтан, доктор (Ph.D) 


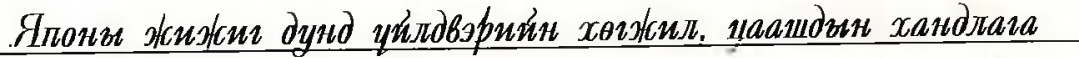

Япон улсын Жижиг дунд үйлдвэрийн суурь хууль /中小企業 基本法/-д “Аж үйлдвэрийн сапбарт 300 сая хүртэл иэний үндсэн хөрөнгө, 300 хүртэл байнгын ажиплагсад бухий үйлдвэр компанийг, Бөөний худапдааны салбарт 100 сая хүртэл иэний ундсэн хөрөнгө, 100 хүртэл ажилпагсад бүхий компанийг, Жижиглэн худалдааны салбарт 50 сая хүртэл иэний ундсэн хөронго, 50 хүртэл ажиллагсад бүхий компанийг, Үйпчилгээний сапбарт 50 сая хүртэл иэний үндсэн хөрөнгө, 100 хуртэл ажиппагсад бүхий компанийг жижиг дунд үйлдвэрт хамруулах" нийт үйлдвэрийн газрын 99\% -ийг жижиг дунд үйлдвэр эзэлж, нийт ажиплагсдын 78\% нь тэнд ажиплаж байна 2 . Одоогоор нийт үйлдвэрийн тоонд жижиг дунд үйлдвэрийн эзпэх хувиар Япон улс Америк, Европын хопбоотой ойролшоо байгаа. Харин жижиг дунд үйлдвэрт ажиллагсдын тоогоор Япон хамгийн өндөр хувийг эзэпж байна. Эдгээр үзуупэлт нь тус улсын эдийн засаг, нийгэм, ард түмний аж амьдрапд жижиг дунд үйлдвэр упэмж нөлөөтэй байдгийг харуулж байна. Жижиг аунд үйлдвэр нь Японд орчин уеийн аж үйлдвэржилтийн үйл явц өрнөсен түухийн явцад тодорхой байр суурь эзэлж, тодорхой чүргийг гүйцэтгэсээр иржээ. Тухайлбал, Мэйжийн шинэчлэпийн уеэс буюу XIX, XX зууны зааг уеэс Америк, Европын хөгжингүй орнуудын технологи, менежментийг шууд бопон дам шугамаар нэвтруүпж үйлдвэржилтийн гарааг эхлэхэд Японы уламжлалт амьдралын хэвшлээс үусэлтэй, гэр бүлээр цөм болгосон жижиг бичил хэмжээний үйлдвэрууд нэгэн чухал жигүур нь болж хөгжиж чаджээ. Эдгээр үйлдвэручдэд нэхмэл, сүпжмэл, утас ээрэх гэх зэрэг сүпжмэлийн чигпэлийн үйлдвэруүд, нэрмэл архи, цай зэрэг хунсний чиглэлийн үйлдвэруүд, шавар урлал, шаазан эдлэл, шэцгийн сав ваарын торлийн үйлдвэруүд гоппож байжээ. Эдгээр уламжлалт үйлдвэрууд нь шинэчпэлт, аж үйлдвэржилтийн явцад үйл ажиплагаа нь саарч, устаж үгүй болсонгүй, харин ч цаг уеийн өөрчлөлтөд идэвхтэй зохицон шинэ хэпбэрээр хөгжиж иржээ. Тухайн уед упамжлалт үйпдвэруүд төвпөрсөн бус нутгийн ижил төрлийн үйлдвэруудийн нэгдэл, хамтпаг, мэдээлэл цуглуулах, хүргэх болон зохицуупагчийн үурэг гүйцэтгэдэг бөөний худапдаачид, технопогийн болон менежментийн талаар упамжлалт үйлдвэрийг дэмжин туслах чурэгтэй улсаас байгуупсан шинжилгээ туршилтын газар зэрэг опон субьектийн гүйцэтгэж байсан үүргийн тапаар японы судлаачид хөндөн бичжээ ${ }^{3}$. Мөн тухайн бүс нутгийн төрел бүрийн сургуулиуд ч хуний неөцийг бэлтгэхэд чухал уүрэг гүйцэтгэж байжээ.

Харин Япон улсын 1930-аад оноос олон упсын тавцанд 


\section{Copjlcab}

явуулсан гадаад улс төрийн бодлого, дайны уей̆н эдийн засгийн нөхцөл байдиын улмаас жижиг дунд үйлдвэрууд армийн хэрэгцээний зориупалтаар дайчлагдах, хучээр нэгтгэгдэх, үйл ажиллагаа нь хязгаарлагдах, чөпөөтэй ажилпах нөхцөл нь хаагдах зэрэг бэрхшээл тохиолдож байв. Гэвч цэрэг армийн хэрэгцээнд бүрэн хэмжээгээр дайчлагдсан том үйлдвэртэй харыцуулахад жижиг дунд үйлдвэр нь дайны дараа ард иргэдийн хэрэгцээ рүү чиглэсэн үйлдвэрлэлд шуурхай шилжих боломжоор давуу байснаараа улс орны эдийн засгийн сэргэлт болон ард түмний аж амьдрал, нийгмийн хөгжилд чухал үүрэг гүйцэтгэж чаджээ. Дайны дараа ийнхуу жижиг дунд үйлдвэрийн чүрэг упам нэмэгдэж ирсэн хэдий ч түүхий эд материал, хорөнгийи гүнзгий хомсдоптой тулгарч, ийм нехцөл байдпын дунд 1947 оны 5 дугаар сард Бух Японы ЖДҮ-ийн Зөвлөл, 1948 оны 3 дугаар сард Японы ЖҚДҮ-ийн холбоо гэсэн упсын хэмжээний байгууппагууд үусэн байгуупагджээ. Энэ нь ЖДҮ-ийн дуу хоолой хучтэй болоход нөлөөпж, упмаар ЖДҮ-ийг дэмжих төрийн бодлого идэвхжиж, 1948 онд Худалдаа, аж үйлдвэрийн яамны ЖКДҮ-ийн газрыг байгуупжээ.

ЖДҮ-ийн хорөнгө санхуужилтийг дэмжих талаар засгийн газраас удаа дараа арга хэмжээ авч явуулсан байна. Энэ хүрээнд 1949 онд Иргэдийг санхуужуупэх төрийн сан /国民金融公庫/, 1953 онд ЖДҮ-ийг санхуужуупэх төрийн сан /中小企業金融公庫/ байгуупжээ. Бас 1950 онд ЖДҮ-ийн итгэмжлэлийн даатгалын хууль /中小企業信用保険法/, 1953 онд Итгэмжлэлийн баталгаа гаргах нийгэмлэгийн хууль /信用保証教会法/ тус тус гарч хэрэгжжээ.

Японы эдийн засаг 1950-иад оны дунд уеэс өндөр хөгжлийн шатанд шилжсэн. 70-аад он хуртэл үргэлжилсэн жигд өндөр хөгжлийн энэ уе тус орны эдийн засаг, нийгмийг эрс өөрчилж, ЖДУ ч ихээхэн өөрчлөгдсөн юм. Өндөр хөгжлийн жилучдийн эхний уед эдийн засагт ЖДҮ-ийн эзпэх байр суурь "давхар бүтэц" 二重鉜造/ Гэдэг нэр томьёогоор илэрхийлэгдэж байв. Энэ нь “эдийн засагт газар тариалан болон жижиг бичил аж ахуйн эзпэх хувь өндөр, нэг талаас орчин үеийн том үйлдвэр, нөгоө талаас дээр үеийн хөдөпмөрийн харипцааг хэвээр авч үпдсэн жижиг үйлдвэр, гэр бүлийн аж ахуйд тулгуурласан бичил үйлдвэр, газар тариалан гэсэн хоёр туйлд хуваагдаж, дундаж давхрага байхгүй. Жижиг бичил үйлдвэр нь хөдөлмөрийн бүтээмж доогуур, том үйлдвэртэй харьцуулахад цалингийн болон хөдолмөрийн нөхцлийн япгаа ихтэй, технологийн шинэчлэл яв'́упахад ур ашиг муутай" гэсэн агуулгыг багтаасан нэр томьёо байв. ЖДУ-ийг хамаарах энэхуу "давхар 


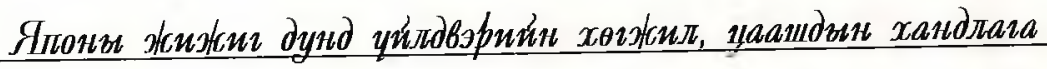

бүтэц" нь эдийн засгийн хөгжипд чөдөр тушаа болж, хөделмөрийн бүтээмж дээшлэх, ДНБ-ний хэмжээ өсөх, технологийн шинэчлэл өргөн хүрээнд нэвтрэх үйл явцыг саатуупах гол нөхшөл болж байна, тиймээс "давхар бүтэц"-ийг арилгахгүйгээр Японы эдийн засаг хөгжихгүй гэх дүгнэлт ${ }^{4}$ ч гарч байв.

"Давхар бүтэц" эдийн засгийн ноцтой асуудал болон тавигдаж байсан 1963 онд Япон улсын Жижиг дунд үйпдвэрийн суурь хуупь батлагджээ. Энэ хуупь “Эдийн засаг, нийгмийн хязгаарлагдмал байдпаас үүссэн ЖДҮ-ийн ашиггүй байдлыг засан сайжруулах, ЖДҮ эрхлэгчдийн бие даасан хүчин чармайлтыг дэмжих, хөдөпморийн бүтээмж болон худалдааны нехциийг дээшлүүпэх" бодпогын зорилт хэрэгжүүпсний ундсэн дээр "давхар бүтшийг өөрчилж, аж үйлдвэрийн бүтцийг сайжруупах боломжийг бүрдүүпэхүйц хэмжээний ЖДҮ-ийг өсгөж хөгжүупэх" зорилт дэвшуүпсэн юм. Уг хуулинд ЖДҮ-ийн бүтцийг дээшпүүпэх, ЖДҮ-ийн шинэчпэл хийх чиглэл тусгасны дагуу үйлдвэрийн газрыг хэмжээний хувьд зохистой түвшинд хүргэх, үйлдвэруүдийг нэгтгэх, хамтын ажилпагааг өргөжуүпэх, зохион байгуулалтын өөрчлөлт хийхийн зэрэгцээ хэт жижиг хэт олон үйлдвэрийн зохистой бус өрсөлдоөнийг таспан зогсоох, худапдааг журампахаар заажээ. Ингэж 1963 онд батлагдсан ЖДҮ-ийн суурь хуупиар ЖДҮ-ийн бодпогыг нэгдсэн тогтолцоонд оруупж, энэ сапбарт хэрэгжих хожмын хууль журмууд тус хуулинд тулгуурлах болжээ. Дээрх суурь хуупинд тулгуурлан хэрэгжүүпсэн бодпогын онцлогийн талаар судлаач Күросэ Наохиро дүгнэхдээ "). Аж үйпдвэрийн бүтцийн бодлогын шинж бүхий ЖДҮ-ийн бодпого хэрэгжсэн, 2. Практикт хэрэгжих тал дээр хамгаалах бодлогыг тупхуү тусгасан, 3. Hard тапыг чухапчилж, soft талыг орхигдуулсан, бодит байдлаас хөндий, улс даяар нэг хэв шинжид хамааруупах байдпаар авч үзсэн, бүс нутгийн онцлогийг тусгаагүй" 5 . гэжээ.

1970-аад он хүртэп үргэпжипсэн эдийн засгийн жигд өндөр хөгжлийн үр дүнд Японы эдийн засаг хөгжингүй орнуудын дунд баттай байр суурь эзэлж, Америкийн дараа дэпхийд хоёрдугаарт орох том эдийн засаг болсон. Өмнө өгуүпсэнчпэн Японы ЖДҮ эдийн засгийн жигд өндөр хөгжлийн эхний үед “давхар бүтэц"-ийн дотор доод давхаргыг нь эзэлж, ашиг муутай, хөдөпмөрийн бүтээмж багатай, хөдөлмөрийн нөхцөл хүнд хэмээн тооцогдож байсан бол ЖДҮ-ийг дэмжих төрийн идэвхтэй бодлогын үр дүн, эдийн засгийН эрчимтэй хөгжлийн явцад Японы аж үйлдвэрийн бүтцийн чухал хэсэг болж чадах хэмжээнд хүртэл шинэчпэгдэн хөгжжээ. Үүнд 1. Жигд өндер хөгжлийн жипүудэд шинээр сургуупь төгссөн залуу 
ажиппах хүчин хөдөпмерийн зах зээлийг тэтгэсэн, мөн ЖДДҮ-Үуд өөрсдөө тоног төхөөрөмжийн хөрөнге оруупалт идэвхтэй хийсний үр дүнд том үйпдвэр болон ЖДҮ-ийн хөдөпмерийн нөхцлийн япгаа мэдэгдэхүйц багасч иржээ 2 Эдгээр үйлдвэрийн дундаас ЖДҮ-ийн хэмжээнээс давж гарсан дунд хэмжээний үйлдвэр /中規模企業/ гэгдэх шинэ маягийн үйлдвэрууд ч төрөн гарч, хөгжиж эхэлсэн байна. 3 ЖДҮ тооны хувьд упам өсч иржээ. ЖДҮ-ийн суурь хуупинд зохистой бус өрсөлдөөн үүсгэх нөхцлийг бий болгох “хэт олон, хэт жижиг” байдлыг хапах зорипт дэвшүупж байсан хэдий ч жигд өндөр хөгжил нь ЖДҮ шинээр байгуулагдах боломжийг нээсээр, ЖДҮийн тоо жипээс жипд нэмэгдэх үйл явц 80-аад оны суүп хүртэп Үргэлжилсээр байлаа.

80-аад онд Японы хагас дамжуулагчийн үйлдвэрлэлийн технологи эрс дээшипж, гэр ахуйн цахилгаан бараа, компьютерийн эд анги, машин техник зэрэг бутээгдэхуүний өрсөпдөх чадвараар дэпхийд ноёлох болж, эрчим хүчний хэмнэлттэй, байгаль орчинд ээптэй технологи, цаг уеийн шаардлагад нийцсэн бутээгдэхуун нь дэлхий нийтийн анхаарлыг татаж байв. Мөн жигд өндөр хөгжлийн эхэн уеэс хурдтай хөгжиж ирсэн автомашины үйлдвэрлэл ч 70-аад онд Тоёота загварын үйлдвэрлэлийн систем нь зардал, чанарын хувьд олон упсын хэмжээнд тэргүупэх зэргээр японы үйлдвэрийн брэнди дэлхийн захх зээлд байр сууриа эзэлсэн юм. Японы үйлдвэрийн дээрх амжиптын чухап тупгуур нь бараа бүтээгдэхүүний эд анги үйлдвэрпэдэг ЖДҮ байсан юм. Ер нь өнгөрсөн зууны 80-аад он гэхэд ЖДҮ нь упс орны эдийн засгийн бүхий п сапбарт ихээхэн чухал уүрэг гүйцэтгэх болж, том үйлдвэруүдтэй харилцан бие биеэ нөхөн орших хэмжээнд хүрч, өөрийн гэсэн өвөрмөц технопогитой, үйл ажиплагаа, зохион байгуулалт нь маш уян хатан, эдийн засгийн нөхцөл байдалд хурдан шуурхай зохицож чалдаг гэх зэрэг онциог шинжийг бүрдуУлж, хөгжлийН өндөр түвшинд нэгэнт хүрээд байв.

Японы үйлдвэрпэлийн системийн давуу талын гол хучин зуйлийг ЖДҮ-ийг хамруулсан хөделмөрийн хуваарийн тогтолцоо буюу Японы шитаукэ систем гэдгийг судпаачид олонтаа тэмдэглэсэн байдаг. Шитаукэ системийн талаар Эдийн засгийн толь бичигт тодорхойлсноор "Захиапагч үйлдвэр нь захиалга хүпээн авагч /шитаукэ/ үйлдвэрт бутээгдэхуун, эд ангийн үйлдвэрпэл, боловсруулалт, засвар зэргийг шууд захиалж хийлгэх тогтолцоонд суурлисан үйлдвэрлэлийн өвөрмец хэлбэр. Захиалагч үйлдвэр нь менежментийн нооцийн давуу талаа ашиглан худалдаанд монопоп эрх эдпэх, шитаукэ үйлдвэрийн үнэ тогтоох үйл ажилпагаанд 


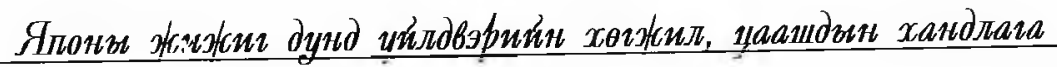

нөлөөпөх зэргээр зах зээлд ноёлох байр суурьтай байдаг. Бизнесийн ийм харипцаанаас уүдэн захиалагч болон захиалга хулээн авагч үйлдвэрийн хооронд захирах, захирагдах харипцан хамаарап тогтдог", мөн "монопоп эрхтэй том үйлдвэрт ажлыг нь хөлсөөр хийдэг, ажиппах хүч нийлүүпдэг, жижиг дунд, бичил үйлдвэр нь эдийн засгийн тогтолцоонд чухал хучин зүйл болж, том үйлдвэрт хараат байдпаар зохион байгуулагдсан байдал" ${ }^{\prime 7}$ гэжээ.

Японы аж үйлдвэрийн бүтшийн чухал онциог болох шитаукэ тогтолцооны эхлэл, мөн шитаүкэ хэмээх нэр томьёо нийтийн хүрээнд хэвшиж эхэлсэн зэрэг нь Япон упс 1930-аад оноос армийн хэрэгцээний аж үйлдвэрийн зохион байгуупаптын хүрээнд жижиг дунд үйлдвэрийг хүчээр шитаүкэ болгон дайчипж байснаас Уудэлтэй. 1941 онд шитаукэ үйлдвэруүдийг том үйлдвэрийн хамТын ажиплагаат үйлдвэр маягаар нэр томьёог өөрчипж байв. Гэвч дайны дараа эдийн засаг сэргэж эхлэхэд, 1948 оноос жижиг дунд үйлдвэрууд дахин шитаукэ байдлыг сэргээх бопжээ. Энэ нь тухайн үенйн технологийн шинэчлэл, аж үйлдвэрийн төрөлжилтийн явц шитаукэ ЖДҮ-т өсч хөгжих шинэ бопомжийг олгож эхэпсэнтэй холбоотой байжээ. Түүнийг залган жигд өндөр хөгжлийн жилүудэд систем шинээр эмхлэгдэж, ганц үйлдвэрийн захиалгыг дагнасан жижиг дунд үйлдвэрийн давхарга, түуний дээд талд захиалагч том үйлдвэр гэсэн аж үйлдвэрийн пирамид хэлбэрийн бүтэц өөрөөр хэлбэл аж үйлдвэрийн кэйрицу: тогтолцоо бүрэлдэж, хөдөлмөрийн бүтээмж дээшлэх, өрсөлдөөнийг идэвхжүулэхэд түпхэц болжээ. Энэ үед ЖДҮ-Үудийн хувьд нэгд, жигд өндөр хөгжпийн жилуүдэд аж үйлдвэрийн сапбарын үйлдвэрпэл эрчимтэй өргөжих явцад урьд ЖДҮ-ийн хүрээнд багтаж ирсэн шитаукэ үйлдвэрууд хогжин, хэмжээний хувьд тэлж, байр суурь нь батжиж ирсэн. Ялангуяа ЖДҮийн дотроос шитаүкэгийн байр сууриа хадгалсан хэвээр оргөжин хөгжсеөр ЖДДҮ-ийн хэмжээнээс давж гарсан шинэ үйлдвэрууд

\footnotetext{
: Ямар нэгән үйлдвэр корпораци хувьцаа эзэмших, мэргэжилтэн томилж ажиллуулах, хөрөнге оруулалт, түүхий эд бүтээгдэхүүн нийлүүлэх, шитаүкэ харилцаа зэргээр дамжуулан бусад үйлдвэрийг нөлеөндөө оруулах топтолцоо. Кэйрицү үйл ажиллагааны зорилго нь өөрийн компанийн бүтээгдэхүүний нийлүүлэх түншийг баталгаатай байлгах, байр сууриа өргөжүүлэх, үйлдвэрлэлийн бусад салбарт үйл ажиллагаагаа ергөтгөх, шитаүкэ үйлдвэртэй болох зэрэт оршино. Кэйрицү тогтолцоо нь том аж үйлдвэрээр толгойлуулсан пирамид хэлбэрийн бүтэц бүхий үйлдвэрүүдийн төвлерөлийг үүсгэдэг. Өөрөөр хэлбэл хувьцааны өмчлел, мэргэжилтэн томилгоо, санхүүжилтийн талаар нягт хамааралтай шууд охин компаниас эхлээд нэг субьектийн хувьцаа эзэмших, мэргэжилтэн илгээх хэмжээний харьцангуй хамаарал багатай кэйрицү үйлдвэр, улмаар үйлдвэрлэл, технологи, тоног төхөөрөмж, материал, худалдаа, борлуулалт, санхүү хөрөнгийн харилцаа бүхий менежментийн хамааралтай кэйрицү үйлдвэр, анхдагч, хоёрдогч шитаүкэ жижиг дунд үйлдвэр гэхчлэн том групп болж зохион байгуулагддаг.
} 
олноор бий болсон, Хоёрт, эдийн засгийн жигд өндөр хөгжлийн явцад асар олон ЖДҮ шинээр байгуулагдаж, шинээр уүсэн байгуулагдсан тэдгээр үйлдвэрийн олонхи нь тус тусын салбарт шитаукэ үйлдвэрийн тогтолцоонд орсоор байсан. Үүгээрээ жигд өндөр хөгжил нь ЖДҮ-ийн хувьд шитаукэ болж том үйлдвэрээс захиапга авах бопомжийг улам нэмэгдүүпж, шинээр шитаүкэ-д орох явдлыг ч улам түргэтгэсээр байсан гэх зэрэг бодит өөрчлөлт гарчээ.

Шитаүкэ үйлдвэр хэлбэрийн хувьд 1980-аад оны сүүлч гэхэд еренхийдөо дараах 3 чиглэл тухайлбал, 1. Цаашид тодорхой нэг том үйлдвэрийн шитаукэ байр сууриа упам бататгаж, тухайн брэндийн бүтээгдэхуүнд дагнан оролцох чиглэлтэй үйлдвэрүуд, 2. Олон тооны захиалагч том үйлдвэртэй байж, зохион бүтээх чадавхиа дээшлүупэн, бүтээгдэхуунээ олон үйлдвэрт нийлуүпдэг, өөрийн дагнасан брэндийн эд анги үйлдвэрлэх, боловсруулах чиглэлийн үйлдвэруүд, 3. Өөрийн үйлдвэрт шинэ бутээгдэхуүн үйлдвэрлэх чадавхиа бэхжүүлж, зах зээлд борлуулах хүчин чадал бүхий бие даасан үйлдвэр болох зорилго бухий үйлдвэрүүд ${ }^{8}$ гэсэн чиглэлээр оршиж байв. Энэ үеийн онцлогийн талаар захиалагч том үйлдвэр болон шитаукэ ЖДҮ-ийн хоорондын харилцааны ерөнхий хандлага урьдын босоо чиглэлийн захирах, захирагдах шинжтэй бизнесийн харилцааны удаан хугацааны хаалттай бүтцээс үйлдвэрлэлийн төрөл, салбарын хувьд харилцан адилгүй ч нээлттэй, харьцангуй тэгш эрх бүхий шитаукэ тогтолцоо болж, нийгмийн хөдөлмөрийН хуваарьт шіинэчлэлт гарчээ ?

Шитаукэ үйлдвэрийн талаар төрөөс явуулах бодпогыг 1956 оны "Шитаукэ үйлдвэрт хийх төлбөрийг хуганаа сунгахыг хориглох хууль" /下請代金支払遅延防止法/, 1970 оны “Шитаукэ жижиг дунд үйлдвэрийг хөгжүүпэх хуупь" /下請中小企業振興法/-иар зохицуупан хэрэгжүупж ирсэн бөгөөд захиалагч том үйлдвэр давуу байр сууриа хэтруүлэн ашиглах явдлыг хязгаарлах болон монополийн эсрэг бодпогын хүрээнд шитаукэ үйлдвэрийн бизнесийн орчин /өрсөпдөөний орчин/-ыг сайжруулах, ялангуяа шитаукэ ЖДҮ болон том үйлдвэрийн харилцан эрх тэгш байр суурийг амьдрал дээр хэрэгжүүпэх, ЖДҮ биеэ даан хөрөнгийн хуримтпалтай болох нөхцлийг /шитаүкэ үйлдвэрийн бүтээгдэхүүний үнийг зохистойгоор тогтоох/ бүрдучпэх зэрэг, чиглэлээр бодлогын арга хэмжээ авчээ.

Өмнө өгүупсэнчлэн 50-иад оны үед ЖДҮ тоогоор хэт олон, хэмжээгээр хэт жижиг, хоцрогдсон технологитой, хөдөлмерийн хүнд нөхцөлтэй, цалингийн ялгаа ихтэй эдгээр нөхцел нь улс орны 


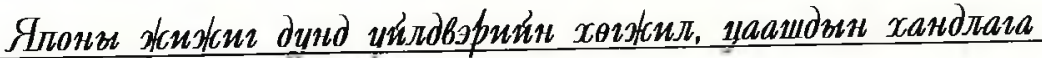

эдийн засгийн хөгжлийг хойш татаж байгаа гэх үзэл давамгайлж байсан боп харин 80-аал он гэхэд ЖДҮ-ийн тапаарх дээрх үзэп бодоп эрс өөрчлөгдөж, ЖДҮ-ийн эдийн засгийн хөгжилд оруупж буй хувь нэмрийг тэмдэгпэх болжээ. Японд 1963 оноос жил тутам нийтлэгдэж ирсэн “Жижиг дунд үйлдвэрийн Цагаан ном"-ын 1984 оны хэвпэлд "Сүупийн уед боловсруулах, угсрах чигпэлийн аж үйлдвэр үпэмж хөгжиж ирсэн нь үйлдвэрпэлийн хуваарийн өндөр үр ашиг бүхий шитаүкэ бүтэц байгаатай хопбоотой" ${ }^{10}$ гзжээ. Энд Японы үйлавэрлэлийн шитаүкэ бутцийн онцлогийг Өмнөд Солонгос болон Америктай харьцуупж, 1. Үйлдвэрийн гадна талд хийж буй хувь өндөр, 2. Үннйг хоёр тал харипцан тохиропшсоны үндсэн дээр тогтоодог, 3. бүтээгдэхүуний чанарын өндөр шаардпага тавигдлаг, 4. Захиалагч том үйлдвэрийн зүгээс байнгын удирдпага, дэмжлэг үзүүпдэг зэрэг нь Японы үйлавэрийн тогтопцооны онцлог хэмээн дурджээ. Тэгвэл 1986 оны Цагаан номонд "Манай упсын шитаукэ бүтэц нь 1. Ажип үүргийн үр ашигтай хуваарлипт, 2. Мэдээппийн зардиын хэмнэлт, 3. Мэдээллийн шуурхай, саадгүй чанар зэрэг талаар маш үр ашигтай үйлдвэрлэлийн тогтолцоо болж чадсан" гэжээ.

Японы шитаүкэ системийн онцлогийн талаар доктор Үэда Хирофуми судалгаандаа “1. Захиалагч талын хувьд үйлдвэрийн гадна тал дахь үйлдвэрлэпийн хэмжээ ихэнхн хувийг эзпэх хэдий ч хопбоотой ажилпаж захиалга өгдөг гадна талын харилцагч цөөнтэй байдаг. Бүтээгдэхүун захиалж хийлгэдэг тодорхой цөөн тооны үйлдвэртэй маш нягт холбоо тогтоосон байдгаар онциогтой. 2. Захиалагч болон захиалга хүпээн авагч талын хамтын ажилпагаа удаан хугацаагаар үргэлжилдэг. Энэ нь анхнаас зориуд төлөвлөсөн харилцаа бус харин эдийн засгийн удаан хугацааны өсөлт болон үйлдвэрпэп тогтвортой өргөжиж байсны үр дүнд бий болсон харипцаа байдаг. 3. Захиалагч болон захиалга хүлээн авагч талын ажил хэргийн харилшаа хопбоо нь удаан жилийн хамтын ажиллагааны зарчим дээр тупгуурладаг. Өөрөөр хэлбэл олон жилнйн нөхөрлөлийн үндсэн дээр хоёр талын худапдаанд гарах янз бүрийн асуудлыг зохицуупж чаддаг. 4. Чанар (Quality), зардап (Cost), хүпээлгэн өгөх хугацаa (Delivery) зэрэг нь хатуу зохион байгуулаптанд байлаг. QСD-ийн удирдлага, зохион байгуулапт нь захиалагч том үйлдвэр болон шитаукэ ЖДҮ-т адил, нэг арга барилаар хэрэгждэг. 5. Шитаукэ-гийн энэхуү системийн үндсэн дээр мэдээпэл тасралтгуй, шуурхай дамжиж, захиалагчийн эрэпт хүсэптэд шитаукэ үйлдвэр шуурхай, уян хатнаар зохицож, өндөр чанартай, хямд үнэтэй бүтээгдэхуүн нийлуупэгдэж ирсэн" 


\section{Copłcab}

системийн эдгээр онциог шинж нь Японы аж үйлдвэрийн өрсөлдөх чадварыг өсгөсөн гол хүчин зуйл болсон, энэ систем 1970-80-аад онд аж үйлдвэрлэл эрс хурдацтай өргөжиж, ЖДҮ-ийн тоо огцом нэмэгдэж байсан тэр үед батжин бүрэлдсэн ажээ. Ялангуяа жигд өндөр хөгжлийн жилүудийн дараах удаан хугацааны эдийн засгийн тогтвортой өсөлт, түҮний үр дүнд бий болсон үйлдвэрлэлийн тэлэпт нь энэ тогтолцоо батжин төлөвших нөхциийг бий болгожээ. ЖДҮийнхэн цаашдын удаан жилийн хамтын ажиллагааг тооцон тоног төхөөрөмжийн хөрөнгө оруулапт хийж, захиалагч тал ч мөн удаан хугацааны хамтын ажиппагаагаа бодопцон шитаүкэ үйлдвэрийг хөгжуулэхийн тупд дэмжлэг үзуулж иржээ.

Японы шитаукэ системийн гол төлөөлөп нь асар олон тоогоор үйлдвэрлэдэг автомашин, электроник, гэр ахуйн цахилгаан хэрэгспийн том үйлдвэруүдэд эд анги нийлучпдэг төрөлжсөн ЖҚДҮҮуд юм. Ийм үйлдвэр нэхмэл, сүпжмэлийн болон бусад салбарт ч дийлэнх хувийг эзэлж байдаг, тооны хувьд Японы нийт ЖДҮ-ийн талаас илуу хувь нь шитаукэ үйпдвэр байдаг ажээ. Опонхи ЖДҮ нь хөдөлмөрийн нөхцлөөр том үйлдвэрийн газрын хэмжээнд хүрдэггүй, ялангуяа энд ажиплагсад том үйлдвэрт ажилпагсдаас удаан цагаар ажиплаж, доогуур цалин хөлс авдаг, боловсон хүчний хувьд ч их сургуупийг сайн үнэпгээтэй төгсөгчид болон нэртэй их сургуупь төгсөгчид мөн п нэртэй том үйлдвэр компанид ажилд ордгоос ЖДҮ-т сайн боловсон хучин төдий п олддоггүй гэх зэрэг бараан ойлголтууд байдаг. Гэвч ЖДДҮ-ууд нь захиалагчаас ирсэн захиалгыг хулээн авч, түүний дагуу үйлдвэрлэл явуупах төдий үйл ажиплагаатай байдаггүй. Опон ЖКДY захиалагч уйлдвэрт хандсан бүтээпч санаачилга гаргаж, үугээрээ том үйлдвэрийн үйлдвэрлэл эхэлснээс хойших үйл ажилпагаа, түүнчпэн үйлдвэрлэл эхлэхээс өмнөх зураг төслийн шатны үйл ажиппагаанд ч нөлөө үзуулж чаддаг ажээ. Том үйлдвэрийн зураг төсөл, үйлдвэрлэлийн шатан дахь алдаа дутагдлыг шитаукэ уйлдвэрт ипручпж, залруулах аргын талаар захиалагчид санап оруупдаг, чүгээрээ тухайн брэндийн бүтээгдэхуүний чанарын болон бусад үзуүпэлт упам сайжрахад хувь нэмэр оруупдаг байна. Ийнхуу шитаукэ үйлдвэрууд хамтын ажиллагааны явцад идэвхтэй санал гаргаж, захиалагч тал түунийг хянан хэлэпцэж, хулээн авдаг бүтэц нь Японы шитаукэ системийн нэг онциог юм.

Шитаукэ тогтолцооны хөгжлийн ур дүнд 1990-ээд он гэхэд Японд туухий эд материал боловсруулахаас эхлээд тоног төхөөрөмж, эд анги, бүтээгдэхуун үйлдвэрлэх, угсрах бүх процесс бүгд дотооддоо хийгддэг байсан, өөрөөр хэпбэп дотооддоо бэпэн 


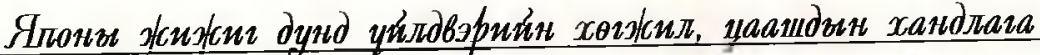

бутээгдэхүун хийх үйлдвэрлэлийн стип бий болсон байв,

Харин 90-ээд оноос хойш, япангуяа хөесөн эдийн засгийн уналтаас хойш Японы аж үйлдвэрийн ийм нөхцөл эрс өөрчлөгдөхөд хүрсэн юм. Тухайлбал, хөосөн эдийн засгийн уналтын дараа аж үйлдвэрийн олон салбарт үйлдвэрлэлийн түвшин өмнөх оргил уеийн хэмжээнд буцаж орж чадаагүй юм. Гадаадад шипжсэн үйлдвэрүудийн тухайн упс дахь үйлдвэрпэл өргөжиж байсан боповч дотоодын эрэлт хэрэгцээний өсөлтийн зогсонги байдап үргэлжилж байв. Мөн бэлэн бүтээгдэхучнийг дотооддоо бурэн үйлдвэрпэдэг байсан загвар өөрчлөгдөж, гадаадад гарсан үйлдвэруудэд эд анги, материал нийлуүлэх чиглэл бий болов. Өөрөөр хэлбэл хөөсөн эдийн засгийн унаптын дараа эдийн засаг суларсан, глобал өрсөлдөөн бий болсон, үйлдвэрууд олноор гадаадад шилжсэн зэргээс болж үйлдвэрлэлийн хуучин хэв маягийг хадгалах боломж алдагджээ. Мөн Хятадын эдийн засгийн өсөлтийн нелөөгөөр үйлдвэрлэлийн зардлын өрсөпдөөн ихэссэн зэрэг олон хүчин зүйл Японы жижиг дунд үйлдвэрт нөлөөлөх болжэз. Том үйлдвэруүд зардал хямдтай гадаадын үйлдвэруүдэд захиалга өгөх чиглэп барих болж, шитаукэ уйлдвэрээ өөрчлех хандпага нэмэгдсэн байна. 1989 оны “Жижиг дунд үйлдвэрийн Цагаан ном"-д "Үйлдвэрлэлийн хуваарлилтын шитаукэ бүтэц худапдааны улам нээпттэй харилцаа руу шилжиж байна. Том үйлдвэр болон шитаукэ үйлдвэрийн хоорондын холбоо супрах хандлагатай болж байна" ${ }^{14}$ мөн уламжлалыг ул харгалзан шилдэг технологитой шитаукэ үйлдвэрийг сонгох, зардлыг чухалчлан, бараа бүтээгдэхуүн нийпуүпэгчийн тоонд гадаадын үйлдвэруүдийг оропцуупах гэх зэрэг хэлбэрээр том үйлдвэрууд шитаукэг сонгох боппоо" гэжээ.

Бизнесийн харилцааны ийм өөрчлөлт нь ЖДҮ-ийн өмнө цөөн бус шинэ асуудпыг гаргаж иржээ. Тухайлбал, 1. Японы үйлдвэрүуд эд анги нийлуупэх стратегиэ шинэчилснээс дотоодын хуучин бизнесийн харипцаа баталгаатай байх нь тодорхой бус болсон.

2. Үнийн өрсөпдөөн гпобап хэмжээнд өрнөх болж, үйлдвэрпэлийн зардлын өрсөлдөөн шируүссэн. Энэ нь ЖДДҮийн хувьд урьд өмнө байгаагүй хэмжээгээр зардиаа бууруупах шаардпага тулгасан гэсэн үг. Япангуяа Хятад мэтийн дапайн чанадаас нийпуупэгдэх бараа бутээгдэхуун, эд анги маш хямд зардалтай байсан нь Японы ЖДҮ-уудэд өрсөлдөөнд тэсч гарахад хүнд нөхциийг үусгэсэн.

3. Гадаал дахь үйлдвэрээ оролцуупсан глобал нийлуупэлт, урьдын дотоодын үйлдвэрууд хоорондын харилцааг халсан нээпттэй 


\section{Copjcab}

худалдаа нь нэг талаар ЖДҮ-ийн хувьд худалдааны шинэ боломжийг бий болгожээ.

Ийнхуу 90-ээд оноос Японы эдийн засагт явагдсан бүтцийн өөрчлөлтийн явцад том болон шитаукэ үйлдвэруудийн хооронд удаан хугацаагаар тогтож ирсэн харилцаа өөрчпөгдөж, ЖДУ-үүд шитаукэ хамаарлаас гарахыг эрмэлзэх үзэгдэл ч гарч иржээ. Мөн Азийн бүс нутагт үйлавэрлэл сэргэж эхэпсэн, Японы иэний ханш огцом чангарсан зэрэг гадаад дотоод нөхцөл байдал нь ЖЛУ-ийн орчинд эрс өөрчпөлт гаргасан юм. 1996 оны ЖДҮ-ийн Цагаан ном-д "Цаашид технологийн чадавхиа упам дээшлуүлж, зардлыг хямдруулах, шинэ шинэ бүтээгдэхуүн бий болгох шаардиага тупгарч байна. Мөн Азийн бус нутагт үйлдвэрлэл явуулах, технологи шилжуупэх зэрэг опон улсын хэмжээний стратеги боловсруулж ажиллах шаардлага тулгарч байна" "г гэжээ.

Энэ үеэс Японы үйлдвэрууд хямд ажиплах хүчтэй том зах зээлийг зорьж, гопдуу Хятад, Америк болон Азийн орнуудад үйлдвэрлэіээ шилжүупж эхэлсэн юм. 2008 оны байдлаар Японы 17658 үйлдвэр дапайн чанадад үйл ажиплагаа явуулж байв. Үүнээс 13417 нь том аж үйлдвэр, 4241 нь ЖДҮ байв ${ }^{17}$. Гадаад дахь үйлдвэруүдийн талаас илуу хувь $/ 54,9 \% /$ нь Хятад упсал, түүнээс гадна Америк $/ 10,9 \% /$, Тайланд $/ 9,6 \% /$, Гонконг $/ 4,6 \% /$, Индонез $/ 4,6 \% /$ зэрэг оронд ажиллаж, цаашид Вьетнам, Энэтхэгт олноор гарах хандлагатай байжээ. Тэдгээр үйлдвэрууд үйлдвэрлэлийн зардлаа бууруулах, тухайн оронд шинэ зах зээл нээж борпуулаптыг өсгөх, упмаар Японы болон гурав дахь зах зээлд экспортлох зорилготой байв ${ }^{18}$. Гадаадад чйл ажиллагаа явуулж буй эдгээр ЖДҮ болон Японы дотоодод үйлдвэрпэл явуупж буй ЖДҮ-ийн хөдөлмөрийн хуваарийн тухайд Японы зах зээлд зориупсан, өндөр технологи шаардсан, нэмуу өртөг илуу шингэсэн бүтээгдэхуүний үйлдвэрпэл голдуу дотооддоо ажиллаж буй ЖДҮ-т ногдож байна. Гадаадад ажиллаж буй компаниудын хувьд эхний уед "шилдэг боловсон хүчин олж авч ажилпуулах, боловсон хүчин бэлтгэх, цалин хөдөпмөрцйн хөлс нэмэх, цаашипбал валютийн ханшны хөдөлгөөн, бүтээгдэхүуний худапдан авагч олж авах, чанарын хяналт, тухайн орон нутгийн тогтолцооны өөрчлөлттэй зохицох" гэх зэрэг гол төлөв менежментийн холбогдоптой асуудап тулгардаг байна 19

Японд хөөсөн эдийн засаг унаж 10 гаруй жил үргэлжилсэн эдийн засгийн зогсонги байдал, Азийн санхуүгийн хямрал, 2008 оны дэлхийн эдийн засаг санхуүгийн хямрап зэрэг нь эдийн засгийн хөгжилд сөргөөр нөлөөлж, дотоодын эрэлт хэрэгцээ буурч, хямд 


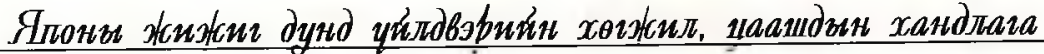

үнэтэй импортын бараа зах зээлд ихээр нэвтэрснээр юмны үнэ унаж, эдийн засагт дефляни бий болсон. Түүний дээр эдийн засагт бүтцийн өөрчпөпт түргэсч, үйлдвэрийн газар шинээр байгуупагдах болон хаагдах узэгдэл тооны хувьд урьдынхаас эрс нэмэгдлээ. Шинээр байгуупагдах үйлдвэрийн тооноос хаагдах үйлдвэрийн тоо илуУ гарч, 90-ээд оноос хойш үйлдвэрийн газрын тоо цөөрөх хандпага үргэлжипж байна. Тухайлбап, жижиглэн худапдаалах салбарт 198186 он, аж үйлдвэрийн салбарт 1989-91он, бөөний худалдааны салбарт 1994-96 оноос үйлдвэрийн газрын тоо чөөрөх хандлага бий болсон нь өнөөг хүртэл үргэлжилж байна. Хэдий тийм боловч 2010 оны байдлаар аж үйлдвэрийн салбарын ЖДҮ п гэхэд нэмүү өртөг шингэсэн бүтээгдэхүуний талаас илуу хувийг үйлдвэрлэж, тус сапбарын гоп хөдөлгөгч хүчний үүргийг гүйцэтгэсэн хэвээр байна. Мөн ЖДҮ нь худалдаа, борлуулалтын хэмжээгээрээ бөөний болон жижиглэн худапдааны 60 гаруй хувийг эзэлж ${ }^{20}$ бараа гүйлгээний салбарт чухал уүрэг гүйцэтгэж байна. Харин уйлчилгээний салбарт шинээр нээгдэх үйлдвэрийн тоо тогтмол өсөлттэй байгаа юм. Шинээр үйлдвэр байгуупагдах явдап нь хуучин ЖДҮ-ийн менежментийн шинэчпэлтэй зэрэгцэн эдийн засгийн идэвхжилд чухал уүрэг гүйцэтгэдэг гол хүчин зүйл юм. Үйлдвэр уүсгэн байгуулагчдын хүчин чармайлтыг дэмжих тухайлбал “ЖДҮ шинээр байгуулахыг хөхуүлэн дэмжих үуднээс төрөөс үйлдвэр байгуупахтай холбогдуулан мэдээплээр хангах, мэргэжил дээшлуупэх сургаптыг улам боловсронгуй болгох, санхуужилтийг шуурхай болгох талаар бодпогын арга хэмжээ авахын зэрэгцээ үйлдвэрийн газар байгуупагдахын ач холбогдол, шаардлагын талаарх нийт иргэдийн мэдиэг ойлгс.птыг гунзгийрүүпэхэд тус дөхөм үзуүпэх '22' тухай заалтыг 1999 онд шинэчлэгдсэн Жижиг дунд үйлдвэрийн шинэ суурь хуупинд тусгажээ.

ЖДҮ-ийн цаашдын нөхцөл байдапд зайлшгуй нөлөөлөх бас нэг хүчин зүйл нь Японы нийгмийн тулгамдсан асуудал болоод буй хүухдийн тоо цеөрөх, нийгэм насжих үйл явц юм. Японы Нийгмийн хамгаалал, хүн амын асуудап судлах институтийн судалгаагаар Япон упсын нийт хүн амын тоо 2005 онд анх удаa өмнөх оныхоос буурсан үзуүлэлт гарчээ. УГ судалгаанаас үзэхэд 2035 он гэхэд нийт хун ам 2008 оны хун амын 87\% буюу 110 сая 670 мянга болж цөөрөх тооцоо гарчээ. Мөн 15-64 насны буюу хөдөпмөрийн насны хүн амын тоо буурах хандлага 1996 оноос бий болсон бөгөөд эдгээр бодит байдап нь ЖДҮ-ийн өмнө боловсон хучний асуудап, үйлдвэрийн хойчийг залгамжлах асуудал, технологи, ур чадварын 
тувшингээ шаашид хадгалж авч явах асуудал зэрэг бэрхшээлийг бий болгосоор байна.

Японы эдийн засаг, нийгмийн ирээдүйн хөгжилд жижиг дунд үйлдвэрийн гүйцэтгэх Үүргийг сүүпийн уед улам чухалчлан авч үзэх болпоо. Японд $\mathrm{XX}$ зууныг том бизнесийн цаг уе гэж хэпж бопох бол XIX зууныг жижиг дунд үйлдвэрийн зуун гэж хэлж болно гэх хандиага ч гарч, жижиг дунд үйлдвэрийн цаашдын хөгжилд ихээхэн найдлага тавьж байгааг ихэнх судлаачид дорх хэдэн хүчин зүйлтэй холбон узэж байна. - Эдийн засгийн опон салбарт оршиж буй ЖДҮ менежментийн чадавхиа ашигпан шинэ сапбарт гарч, шинэ бутээгдэхуун, шинэ үйлчипгээ бий болгох чиглэпээр ихээхэн хүчин чармайлт гаргаж байгаа бөгөөд үүгээрээ Японы эдийн засаг, нийгмийн упам төгөлдөршсөн шатанд аж үйлдвэр хөгжих эх сурвалж нь болж өгех бололцоотой. Ялангуяа цомхон бүтэц зохион байгуупалтаараа том үйлдвэрээс япгарах ЖДҮ-ийн хувьд нөхцөп байдлын өөрчпөлтөд уян хатнаар зохицох чадвар, өөрөөр хэлбэл үйл ажиплагааны хурд шаардах цаг үед зохицон ажиллах чадвар нь дээрх боломжийг бий болгоно.

Японы хэрэгпэгчид, ард иргэдийн хэрэгцээ опон талтай, өөрчпөлт ихтэй байдаг, энэ нь тал бүрийн бүтээлч сэтгэлгээ хөгжүупсэн ЖДҮ-ийн хувьд оршин тогтнох боломжийг шинээр нээж байдаг. СүҮпийн үед амьдралын өндөр чанар, аюулгүй байдал, орчны эруул ахуйн шаардпага улам бүр дээшилж байгаа энэ нөхцөлд ЖДҮ-ийн гүйцэтгэж чадах үүрэг упам нэмэгдсээр байна.

- Ажлын байрыг шинээр бий болгож байдгийн хувьд ЖДҮийн гүйцэтгэх ҮҮрэг үпэмж их. Түүнчилэн ЖДҮ нь ард түмний аж амьдрапд хамгийн ойр байдгаараа ажил хөдөлмөрийн олон хэлбэр, эдийн засгийн үйл ажилпагаа явуулах боломжийг оршин суугчдад олгож чаллаг. Эмэгтэйчүуд, өндор настнуудад ажлын байрны боломж олгох талаар ЖДҮ тухайн бүс нутаг, нийгэмдээ чухал Үүргийг гүйцэтгэж чаддаг.

- Японы ЖДҮ тооны хувьд опноос гадна газар зуйн байрпалаар тодорхой бус нутагт төвлөрч, харилцан нягт холбоотой сүпжээ, хөдөлмөрийн хуваарийг тогтоож ирсэн нь үйлдвэрлэлийн үр ашгийг нь улам дээшлуүпж өгдөг.

- Японы том үйлдвэр болон ЖДҮ-ийн хоорондын харипцаа нь шитаукэ систем хэмээн нэрлэгдэж, тус упсын аж үйлдвэрийн хүчирхэг байх нэг нөхцөл хэмээн тооцогдож ирсэн бөгөөд Японы том болон ЖДҮ-ийн хамтын ажиллагаа нь цаг үей̆н өөрчлөлтийн явцад улам олон талтай болсоор байна. 


\section{ЭШЛЭЛ, 3УУПТ:}

1 中小企業基本法、第 1 章、第 2 条、1999

2 商工総合研究所編「日本の中小企業、図説」2010、x.

3 植田浩史、桑原武志、本多哲夫、義永忠一「中小企業 ベン チャ一企業論」有斐閣コンパクト、2011、北島滋、山本篤民「中小 企業研究入門」文化書房博文社、2010、黑瀬直宏「中小企業政策」 日本経済評論社、2006 r. M.

4 植田浩史、桑原武志、本多哲夫、義永忠一「中小企業ベン チャ一企業論」有斐閣 コンパクト、2011、x. 29

5 直宏黒瀬「中小企業政策の総括と提言」同友館、1997、x. 135-141

6「経済学辞典、第3版」岩波書店、1992、x． 587

‘「有斐閣経済辞典」第4版、2002年

8 个経済学辞典、第3版」岩波書店、1992、x. 588

9 мөн тэнд

10「中小企業白書、1984年版」第2部、第6章、x. 389

11 中小企業白書、1984年版、X. 64

12 植田/浩文、桑原武志、本多哲夫、義永忠一著「中小企業 ベンチャ一企業論」有斐閣 コンバクト、2011、x. 109-110

13 植田浩文、桑原武志、本多哲夫、義永忠一著「中小企業

ンデャ一企業論」有斐閣コンバクト2011、x. 115

14 中小企業白書、1989年版、x. 106

15 中小企業白書、1989年版、X. 108

16 中小企業白書、1996年版、X. 203

17 商工総合研究所 編「日本の中小企業 2010、図説」 2011、x. 42-43

$18 \mathrm{M} \ominus \mathrm{H}$ Тэнд

19 商工総合研究所 編「日本の中小企業 2010、図説」 2011、x. 47

$20 \mathrm{M} \Theta \mathrm{H}$ Тэнд, Х. 10

21 中小企業基本法、第 2 章、第 1 節、第 13 条

22 中小企業白書、2010 年版、X. 131

\section{АШИГПАСАН МАТЕРНАЛ}

1. 中小企業基本法、1968 年、1999 年

2. 岩波書店「経济学辞典」第 3 版、1992 年

3. 有斐閣「経済辞典」第 4 版、2002 年

4. 黒瀬直宏「中小企業政策」日本経済評論社、2006

5. 植田浩史、桑原武志、本多哲夫、義永忠一「中小企業 べ 


\section{Coppicab}

ンチャー企業論」有斐閣コンバクト、2011

6. 北島滋、山本篤民「中小企業研究入門」文化書房博文社、 2010

7. 商工総合研究所 編「日本の中小企業 2010、図説」2011

8. 直宏黒瀬「中小企業政策の総括と提言」同友館、1997

9. 中小企業庁 編「中小企業白書」1984年版、1989年版、 1991年版、1996年版、2010年版

10. 経済企画庁 編「経済白書 平成 4 年版」

11. 中村秀一郎 著「2 1 世紀型中小企業」岩波新書、1992

12.Т. Намжим "Япон орон тоймпон харвап" УБ., 1999

13. "Япон хэл, соёл" эмхэтгэл, УБ., 2008

14. "Зуүн хойт Ази судлал" сэтгүүл, 1996, $\square 1 / 7 /$ 